Journal of Political Science
(A Peer-Reviewed, Open Access Journal and Indexed in NepJOL)
ISSN 2362-1273 (Print); ISSN 2773-8132 (Online)
Volume 21, Special Issue, August 2021
http://ejournals.pncampus.edu.np/ejournals/jps/
Published by
Department of Political Science, Prithvi Narayan Campus, TU, Pokhara, Nepal
Email: polsc@ @ncampus.edu.np; URL: www.pncampus.edu.np

\title{
Women Participation in Local Development: A Study of Kaski District
}

\author{
Girdhari Dahal, PhD \\ Department of Political Science \\ Prithvi Narayan Campus, Pokhara
}

Corresponding Author: Dr. Girdhari Dahal, Email: gddahal1234@gmail.com

DOI: https://doi.org/10.3126/jps.v21i1.39285

Copyright 2021@ The Publisher and Author/s. The journal is licensed under a Creative Commons Attribution-ShareAlike 4.0 International License.

Submitted 16 July 2021; Reviewed 19 July 2021; Accepted 28 July 2021; Published 20 Aug. 2021

\begin{abstract}
The purpose of this study is to examine the women participation in local development of Kaski district in Nepal. The nation provides equal opportunities to the women. Despite that, they are strong enough and empowered in local development? Nepalese women are struggling for equal opportunity in society. This paper is qualitative research. It is based on primary and secondary data based on descriptive and analytical paper. In the local election held in 2017, 152 women were elected to the local government in Kaski district. They are Dalit and non-Dalit both. Constitutionally thirty-three percent women are required to be the participants on each level of the government of Nepal. It is a legal provision for participation in local governments. Similarly, women are the participants in the federal, provincial and local governments of Nepal. The constitution has provided women participation on policy level as well as civil service, Nepal Police and Nepal Army and other sectors of the nation. Now, the federal democratic republic nation of Nepal has been practicing inclusive democracy. It is a great achievement for the Nepalese women. Now, 21th century as democratic country like Nepal needs meaningful women participation on a local level. The women need equal opportunity in the social, economic and political sector. Local level of Kaski district women participate with empower on politics as well as development activities as planning, budgeting, judicial leadership. These are the symbolic empowerment of women in local development.
\end{abstract}

Keywords: Development, inclusiveness, judicial committee legitimacy, women participation 


\section{Women Participation in Local Development: A Study of Kaski District}

\section{Introduction}

Women are the major components of the society; without them the society cannot be perfect and civilized. So, women are supposed to have occupied half the space of the sky. In fact, women and men are the essential factors of a human society. Having realised the basic nature of the society in Nepal women are participating in local development. In this study women play a vital role in local government. There are 77 districts in Nepal, among them Kaski district is one where women are participating in local development. Nepal embarked on a new journey as a federal state after the successful completion of local, provincial, and federal elections in 2017 (Samjhauta Nepal, 2018). According to the Human Development Report, "participation means that people are closely involved in the economic, social, cultural and political process that affects their lives" (Human Development Report, 1993:1). Women's role in decision making is one of the most important questions for the consideration of their empowerment. Keeping in mind the importance of women's participation in decision making, the constitution of Nepal has provided 33 percent women participation on the different levels of the government and all sectors of the nation.

The local elections have changed the political landscape, at least at the local levels, for Nepali women (Samjhauta Nepal, 2018). It is a contemporary issue of Nepal. The women are empowered by the local government after the local election in 2017. In Kaski district there are five local governments. There are four Rural Municipalities and one Metropolitan City- Annapurna, Machhapuchhre, Madi, Rupa are the Rural Municipalities and Pokhara Metropolitan City. These are the local bodies of Kaski district. It is located in the capital city of Gandaki province. Annapurna Rural Municipality has 11 wards - 11 Dalit women and 11 non-Dalit women are elected and one woman openly also elected and vice chairwoman with elected women are 24. Similarly, Machhapuchhre Rural Municipality has 9 wards and total 19 Women are elected. Another Madi Rural Municipality has 12 wards and elected women are 25 and Rupa Municipality has 7 wards and elected women are 15. Pokhara Metropolitan city has 33 wards and elected women are 68 (Local Election Report 2017). They have played a vital role in the society. Devolution of power to local people encourages active political participation as a result of the central government being remote from the local people. Devolution of power to local people at the grass root enhances the legitimacy of the government and its programmes (Amah, 2018). The major role of Rural Municipalities is to institutionalize local governance by creating an enabling environment to promote democratic values and public participation in the decision-making process (Dahal, 2020). If the women are fully participating on the various participatory development issues of local level, they are automatically developing their capacity, leading skills. They are also contributing to the institutional development of democratic processes as they have taken part from the grass root level. 


\section{Women Participation in Local Development: A Study of Kaski District}

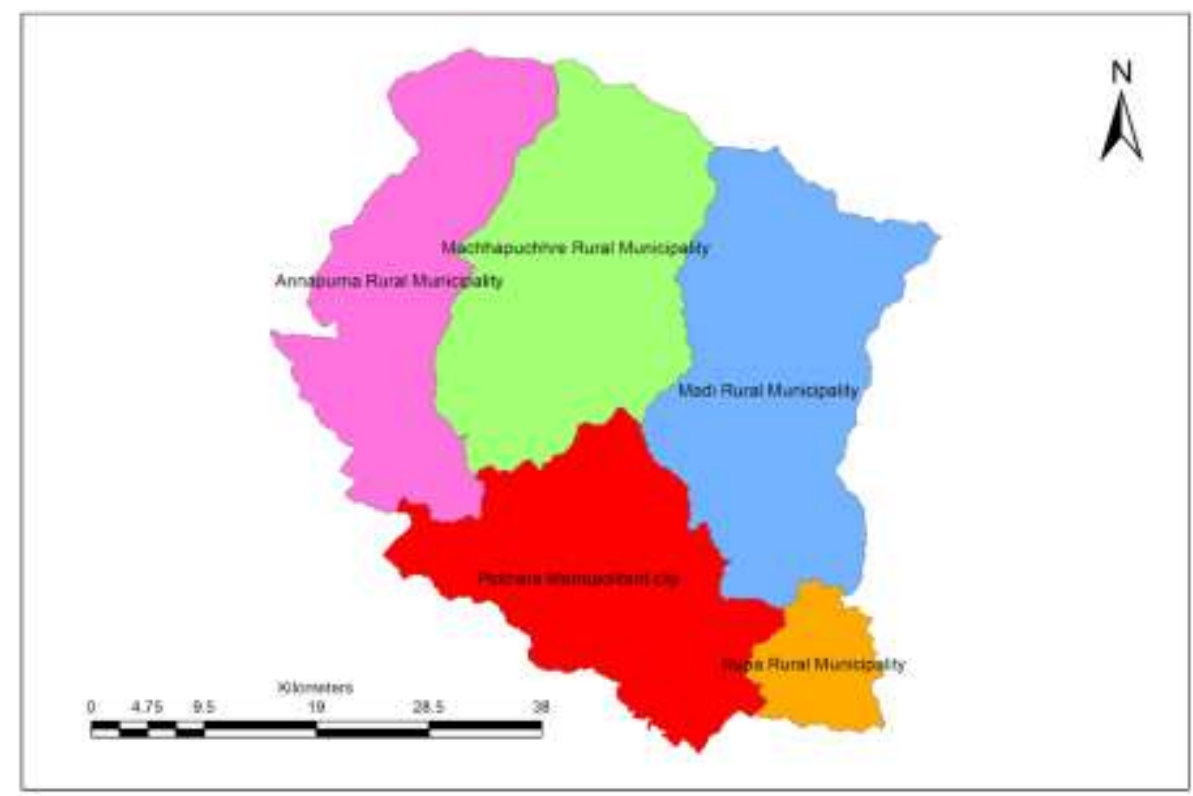

Figure no 1: Kaski District, Source: http://www.dos.gov.np/

In Nepal, women hold constitutional positions including President, Chief Justice, Speaker of the Parliament (Upreti, 2020). Now the President of Nepal is Bidya Devi Bhandari. Similarly, Onsari Gharti Magar was elected the Speaker of the Legislature-Parliamentary of Nepal, in office 16 October 2015 - 15 October 2017. She became the first woman Speaker in the parliamentary history of Nepal. Sushila Karki was the Chief Justice of the Supreme Court of Nepal and the only woman to have held the post. Karki became Chief Justice on 11 July 2016. These are the distinguished achievements of Nepalese women. Women's leadership in the major major organs of the state is the great achievement for their prestige and and honour. They were successful on their post. It is proof for the fact that if the nation provides adequate opportunities to women, they play a vital role to fulfil their responsibilities. Recently, good opportunities are provided for women's participation and representation in local government. It will support and institutionalize democracy from grassroots level. Similarly, women leadership develops at the local level. Women participation on development planning has to created a representative system of local government and a base for participatory democracy in development. The Local Government Operation Act has provisions to delegate powers and functions to the lowest units called the Wards. The Wards are regarded as the very closest units of the people, which ensure the citizens have access to the services to the doorsteps of the people so that they have ample opportunities in services (Acharya, 2018). This research will be fruitful for planners, politicians, women, and the academic sector as a landmark for the women empowerment in Nepal. 


\section{Women Participation in Local Development: A Study of Kaski District}

\section{Objectives and Methodology}

The paper critically examines and analyzes the women participation in local development of Kaski district in Nepal. The paper makes a brief description and analysis of women participation in public policy making and planning practices being followed in municipalities.

This study has used both primary and secondary data. Primary data can be collected in a number of methods. However, the most common techniques are self-administered surveys, interviews, field observation, and experiments. Primary data collection is quite expensive and time consuming compared to secondary data collection (Schwarz, Groves, \& Schuman, 1999). Among them in this research interview has been the most important one. There are various types of interview as informal interview, telephone interview, face to face interview, small group interview, on-site interview, behavioral-based interview, task-oriented interview, stress interview. This research is focused on the primary data which has been collected through the telephone interview. There are various methods applied in research sampling. In this research purposive and judgment sampling method is mainly used. Purposive sampling is a sampling technique in which researcher relies on his or her own judgment when choosing members of population to participate in the study. The respondents are selected through propulsive and judgement sampling methods. Interviews are taken with 7 elected women appendix 1. They are elected on local level as members, vice chairmen, vice Mayor. The respondents provided their convenient time for interviewing. In-depth interview is taken with these respondents on various issues of local development activities. Because of the universal pandemic of Covid-19, for the face to face interviews are not possible. So, the telephone interview was conducted from June 15 to 25, 2021. Thus, the primary data were collected from the fieldwork, mostly through telephone and person-toperson interviews. Secondary data were collected from different books, journal articles, reports, etc.

\section{Literature Review}

The overall development of a country depends upon the maximum utilization of her people, both men and women. In Nepal women comprise nearly half of the total population. But the status of women is much lower than that of men in every sphere of life (Khan \& Ara, 2006). The rationale behind the emergence of the participatory development approach is that the participation and involvement of beneficiary groups develop and strengthen the capabilities of beneficiary groups in development initiatives. This is empowering, and leads to selftransformation and self-reliance thereby ensuring sustainability (Pendirs, 1996; Rahman, 1993; Conyers \& Hills, 1990) Cited by Dinbabo, 2003).

Right of women: (1) Every woman shall have equal right to lineage without any gender discriminations. (2) Every woman shall have the right relating to safe motherhood and reproductive health. (3) There shall not be any physical, mental, sexual or psychological or any other kind of violence against women, or any kind of oppression based on religious, social and cultural tradition, and other practices. Such an act shall be punishable by law and the victim shall have the right to be compensated as provided for in law. (4) Women shall have the right to participate in all state structures and bodies on the basis of the principle of proportional inclusion. (5) Women shall have the right to special opportunity in the spheres of education, 


\section{Women Participation in Local Development: A Study of Kaski District}

health, employment and social security on the basis of positive discrimination. (Government of Nepal, 2015)

According to the constitution of Nepal, Article 84 ensures one- third representation shall have to elect at least one-third of total numbers as women in the Federal Parliament. Similarly, Province and local government of Nepal (Government of Nepal, 2015). Constitution of National Assembly and terms of members: (1) National Assembly shall be a permanent house. (2) There shall be fifty-nine members in the National Assembly as follows:-(a) Fifty six members elected from an Electoral College comprising members of Provincial Assembly and chairpersons and vice- chairpersons of Village councils and Mayors and Deputy Mayors of Municipal councils, with different weights of votes for each, with eight members from each province, including at least three women, one Dalit, one person with disability or minority; (b) Three members, including at least one woman, to be nominated by the President on the recommendation of Government of Nepal. Have institutional development of local bodies capable of bearing responsibility, by providing such responsibility and power at the local level as is necessary to formulate and carry out plans, and constitute local bodies for the development of the local self-governance system in a manner that they are able to make decisions on the matters affecting the day-to-date needs and lives of the people, by developing local leadership (MoFALD, 1999). Local governance is interpreted as the active involvement of the local population within the territorial boundaries of a local government in ensuring improved quality of service and leadership at the local level. Women's participation as councilors and as well as initiatives to enhance the involvement of women and women groups in decision-making, requiring accountability (Ofei-aboagye, 2000). In local development processes, participation by women is that ward committees must include 'equitable representation of women and of a diversity of interests in the ward'. There was a huge gap in terms of knowledge, skills, and power structure between men and women. The Constitution of Nepal (2015) has been promulgated with the essence of making local government more powerful and autonomous. It is for ensuring good governance, strengthening local democracy for sustainable economic prosperity in order to change the rural livelihood of people (Dhital, 2018).

Women are a driving force for rural development in Nepal. Today, rural women are more mobile and capable of earning income, owning enterprises, and holding leadership positions within community interest groups and cooperatives than ever before. These improvements have changed the status of Nepali women and this improvement has been observed in areas such as health, education, income generation, enterprises, land ownership, representation in community groups, and politics (Icimod, 2014).

The positions of Nepalese women are gradually developing in the various sectors of the society. The women play a vital role in the social, economic, and political movement in Nepal. So that women are empowered more in the present context than they were in the unitary system.

\section{Result and Discussion}

\section{Women in Politics}

In Kaski district, there are five local governments such as Pokhara Metropolitan City and four Rural Municipalities. Pokhara Metropolitan City has 33 wards and Annapurna Rural 


\section{Women Participation in Local Development: A Study of Kaski District}

Municipality has 11 wards, Madi Rural Municipality has 12 wards, Machhapuchhre Rural Municipality has 9 wards, Rupa Rural Municipality has 7 wards. Two women members are elected in each ward of all municipalities. Among them one is Dalit woman and another is non-Dalit woman. Similarly, each Municipality vice chairman is a woman and Pokhara Metropolitan City ward number 1 and Vice mayor are women. The elected women in the Kaski district are given in the following table:

Table 1: Women Representation in Local Bodies of Kaski District

\begin{tabular}{lllllll}
\hline SN & Local Government & Wards & $\begin{array}{c}\text { Dalit } \\
\text { Women }\end{array}$ & $\begin{array}{c}\text { Non-Dalit } \\
\text { Women }\end{array}$ & Remarks \\
\hline 1 & $\begin{array}{l}\text { Annapurna } \\
\text { Municipality }\end{array}$ & Rural & 11 & 11 & 11 & 24 (One Vice Chairman) \\
2 & Machhapuchhre & 9 & 9 & 9 & 19 (One Vice Chairman) \\
3 & Madi & 12 & 12 & 12 & 25 (One Vice Chairman) \\
4 & Rupa & 7 & 7 & 7 & 15 (One Vice Chairman) \\
5 & Pokhara & 33 & 33 & 34 & $\begin{array}{l}69 \quad \text { (Member, Ward } \\
\text { Chairmen and Vice } \\
\text { Mayor) }\end{array}$
\end{tabular}

Total Elected Women

152

Source: www.http //local.election.gov.np, 2021

Table No. 1 above shows the elected women of local level in Kaski district in 2017. It is the most important achievement in the women political history of Nepal. The constitution of Nepal is the people's constitution and it provides empowerment to the women in local government. All levels of the government contribute 33 percent in policy level. It will support women leadership development on a local level. Similarly, it will help to institutionalize democracy at the local level. Local government is the miniature government and practice at grass root level as legislature power, executive power and judicial power to the people. Thus, at the local level there are 33 three percent women who participate in the legislature, executive and judicial organ of local government. It is the constitutional political right of women. These participants are almost Dalit and non-Dalit women. All Rural Municipality and Metropolitan City Vice Chairman are women. They have legally defined judicial leadership on the local level. Thus, Kaski district women are empowered in politics. This study observed that a lack of information, lack of resources and government assistance, lack of education, cultural values and discrimination against rural women were the most important factors contributing to the inactive participation of rural women in developments as claimed by Kongolo \& Bamgose (2002) in their study on South African villages. 
Women Participation in Local Development: A Study of Kaski District

\section{Women in Development}

According to respondent 1: Women participation is carried out in each and every ward of Rural Municipalities and Metropolitan City mechanism for overall development of local development. Local governments have been supporting maternal-child welfare centers, women awareness training budgeting and planning on the vice-chairman women programme for women empowerment (Gurung, Sagun Personal communication, 15 June, 2021). At present, all development activities are not complete without women participation. Women are well participating in their local development. Respondent 2: Machhapuchhre Rural Municipality tries to provide women awareness programmes as public service commission training two months each year for their empowerment to the local women. Similarly, women skill development training, capacity development training, sewing and knitting training for women at the local level (Dawadi, K. Personal communication, 25 June, 2021). Respondent 3: There are women focused programs for their employment through the budgeting each year vice chairmen women program for employment of women of Madi Rural Municipality. This year only 30 Lakh rupee for this program and distribution in various titles such as Disabled person diet allowance, legal wariness, capacity develop program, infrastructure development program, income generate program etc. (Paudel, B. Personal communication, 21 June, 2021). Respondent 5: women focused program budgeting 2o million rupee for Dalit women empowerment in various sectors such as women friendly proramme, Agriculture, Veterinary, Tunnel farming, Tractor distribution, Goat Farming, Poultry Framing, income generated program, professional training focus on backward wards 18, 19, 20 and 24, etc. (Gurung, M. Personal communication, 25 June, 2021). Similarly, women help desk management in Pokhara Metropolitan City office.

\section{Women Participation on Local Planning}

Local government is basically an organized social entity with a feeling of oneness. By definition, local government means an intra-sovereign governmental unit within the sovereign state dealing mainly with local affairs, administered by local authorities and subordinate to the state government (Jahan, 1997:92). Women are participants in local planning. All wards have been mobilizing their ward mechanism for planning and identifying tole plan and select plan after that ward assembly Chair by ward chairmen. Women actively participate and select the ward plan and forward Rural Municipality and Metropolitan City. Rural Municipalities and Metropolitan City collect all the local plans and discussions on the five development committees and forward for final approval to the Rural Assembly and Metropolitan City for their approval. This development committee has been composed with 33 percent women participation. These development committees are social development committee, infrastructure committee, good governance committee, environment committee, economic development committee, etc. (Gurung, M. Personal Communication, 23 June 2021). Budget planning committee chaired by the vice mayor and announce the budget ceiling for each development committee. Rural Municipality and Metropolitan City have tried to exercise democratic practice at grass-root level.

\section{Women in Cooperative}

Madi Rural Municipality has a women cooperative program for women empowerment on local level. In the women cooperative in Madi there are 400 women participating. It has been helping and sharing to only women members. The funding of women cooperatives includes grants from Madi Rural Municipality and other organizations. Respondent 7: 


\section{Women Participation in Local Development: A Study of Kaski District}

Women are collecting a monthly nominal amount of saving Rs.50 by shareholding women of Madi Rural Municipality. Similarly, there are other cooperatives that also support women of the local level. They are empowering economically and the women get skillful training from the local government. They are happy from these programs (Shapkota, G. Personal communication, 21 June, 2021). The cooperative supports all Dalit and non-Dalit women who have sufferings and poverty at local level. They have developed leadership also, they select the plan and invest in the field of their area. Such as ward women for one or two Lakh for their women support program.

\section{Dalit Women in Politics}

Dalit women are suffering since a long time in the history. After the federal democratic republic nation Nepal, the siltation of Dalits has been changed. The Constituent Assembly made the constitution of Nepal and it provided Dalit rights. Similarly, by constitutional provision two women are elected on wards of 753 local levels. Among them one Dalit woman compulsory representative on each ward of local level. It is most important achievement for the Dalit women. It is good opportunity for the Dalit women than they had in the previous unitary system. The constitutionally and legally no discrimination between all caste, language, religion but socially and practically there still exists vast discrimination between Dalit and non-Dalit people. The constitution of Nepal provided that the Dalit women are empowering to the politics as well as all sector of the nation. Now in practice reservation on Dalit quota on various sectors of the nation- such as civil service, Nepal police, Nepal army, University service and everywhere Dalit quota reservation for empowerment to the Dalit people. It is a great achievement to participate with them. The nation to provide them meaningful participation to the Dalit people in policy level. Now in Nepal Dalit Constitutional commission is formed. It will support and empower the Dalit people in the various sectors of the nation.

\section{Table 2: Dalit and Non-Dalit Women in Kaski}

\begin{tabular}{ccccc}
\hline SN & Non-Dalit & Dalit & Total & Remarks \\
\hline 1 & 80 & 72 & 152 & $\begin{array}{c}\text { Five Non-Dalit Women vice } \\
\text { Chairmen }\end{array}$
\end{tabular}

Source: www.http //election.gov.np, 2021

Table No. 2 above shows that 72 Dalit women have been representatives in the local election of 2017 in Kaski district. They are elected by the popular vote of the people. It is distinguishing achievement of the Dalit political history of Nepal. The society always dominated the Dalit women but now Dalit women are empowered on the local level. Pokhara Metropolitan City is trying to minimize discrimination between Dalit and non-Dalit women through the 20 million funding for awareness training and empower the Dalit women as backward society respondent 6 as Appendix 1 (BK, H. Personal Communication, 22 June, 2021). The Dalit women are participating on various sectors of the nation as social, economic and political empowerment on local levels. 


\section{Women Participation in Local Development: A Study of Kaski District}

\section{Women in Judicial Committee}

There are five Judicial committees in Kaski district. The constitution provides judicial rights to the local government. And the Vice chairman is the head of the judicial committee of all local governments. In Kaski local government, women are elected as vice chairmen and Vice Mayor. She leads the judicial committee. So, they provided justice to the people from the local level. It is distinguished by the local women leadership. It is a good exercise for women leadership.

Judicial right develops the decision making power at local government. There are women in all local government leadership. Four Rural Municipalities and one Metropolitan City are chaired by women leadership. They examine the local cases at the local level. Pokhara Metropolitan City has solved hundreds of disputes at the local level, and they have made a mediator committee in each Rural and Metropolitan City. It is very much helpful for the local dispute dissolution. Women vice chairmen practice and dispute dissolution at local level. The constitution of Nepal provided the judicial rights to the local level. The local government judicial committee practice and participation and local dispute dissolution at the local level is very important. Mediator committee also helps the judicial organ (MOFALD, 2017). It provided the good nature of the local government as a miniature government and provided to the people goods and service delivery at the nearby center. It is the most important factor of the federal democratic republic nation of Nepal.

Finally, these activities are done by elected women participation at local level. Traditionally speaking Nepalese society is male dominated society. Women are the major part of the society but try to practice social, economic, political and cultural empowerment on the local level of Kaski District. Comparatively women are empowering in various sectors of the local level. Women leadership is developing at the grassroot level. They participate in planning and decision making as well as evolution development activities. Infrastructure development is not enough for overall development at local level. So the local level of human resource development is an important phenomenon.

\section{Conclusion}

Women are suffering and struggling for empowerment. New constitution of Nepal has provided women rights and empowered them legally. Women have acquired a legitimate space in rural political institutions that can raise their marginalized position, though they are still a minority. The constitution of Nepal provides women rights as the nation become federal democratic republic. Now the nation tries to empower women on different policy levels. At present in Nepal women are dominated by male. In Nepal there are no meaningful women participations in politics, economics, social sectors of the nation. But the constitutional and legal rights are theoretically provided to the women 's participation. In fact, in practice women are suffering in society. There is vast discrimination between male and female, the society does not provide equal opportunity to the women. They occupy half space everywhere but socially, economically, religiously there is vast discrimination between male and female. Although, at the local level of Kaski district women are aware and struggle for meaningful participation in the society, they need more meaningful opportunities. Comparatively in Nepal women get a chance and opportunity to lead the nation as President, speaker of the parliament and chief justice of the supreme court. They have great achievements in the political history of Nepal. It is a golden opportunity for women leadership. It has been proved that if the nation or political party provided the 


\section{Women Participation in Local Development: A Study of Kaski District}

opportunity to the women they are found successful in fulfilling their great responsibility. Similarly, at the local level almost all women are vice chairmen all over the 753 local level and lead the judicial organ of local government and provide justice at the local level.

\section{References}

Acharya, K. K. (2018). Local Governance Restructuring in Nepal: From Government to Governmentality. Dhaulagiri Journal of Sociology and Anthropology, 12, 37-49. https://doi.org/10.3126/dsaj.v12i0.22178

Amah, E. I. (2018). Devolution of Power to Local Government: Appraising Local Government Autonomy under Nigerian Federation. Beijing Law Review, 09(02), 275-293. https://doi.org/10.4236/blr.2018.92018

Dahal, G. (2020). Practices of Policy Making and Planning: A Case of Annapurna Rural Municipality in Kaski District. Prithvi Academic Journal, 2352(September), 100-110. https://doi.org/10.3126/paj.v3i1.31289

Dhital, B. (2018). Local Governance Practices in Federal Context: The Case of Gorkha Municipality. Nepalese Journal of Development and Rural Studies, 15, 11-22. https://doi.org/10.3126/njdrs.v15i0.31591

Department of Survey, 2017. http://www.dos.gov.np/

Dinbabo, M. F. (2003). Development theories, participatory approaches and community development. Unpublished Paper. Bellville: Institute for Social Development, University of the Western Cape, November.

http://files/396/Development\%20Theories, \%20Participatory\%20Approaches\%20and\%20Co mmunity\%20Development\%20II.pdf

https://election.gov.np/\%202017

Government of Nepal. (2015). Constitution of Nepal, 2015 (2072 BS).

http://www.lawcommission.gov.np/en/archives/category/documents/prevailinglaw/constitution/constitution-of-nepal

Jahan, M. (1997). The changing structure of local government in Bangladesh: An Overview. Administration, Communication and Society, 1(1), 91-105.

Human Development Report (1993).

http://hdr.undp.org/sites/default/files/reports/222/hdr 1993 en complete nostats.pdf

ICIMOD (2014). Women's Empowerment at the Frontline of Adaptation. https://lib.icimod.org/record/29811/files/WE_14.pdf?type=primary

Kongolo, M., \& Bamgose, O. O. (2002). Participation of rural women in development: A case study of Tsheseng, Thintwa, and Makhalaneng Villages, South Africa. Journal of International Women's Studies, 4(1), 79-92.

Khan, M. R., \& Ara, F. (2006). Women, participation and empowerment in local government: Bangladesh Union Parishad perspective. Assian Affairs, 29(1), 73-92. 


\section{Women Participation in Local Development: A Study of Kaski District}

MoFALD. (1999). Local self-governance act, 2055 (1999). 2055(5), 1-161.

MOFALD. (2017). Local Government Operation Act, 2017, Ministry of Federal Affairs and General Administration, Government of Nepal. 1-86.

Ofei-aboagye, E. (2000). Promoting the Participation of Women in Local Governance and Development: The Case of Ghana. Development, June, 14-15.

Upreti, B. R. (2020). Journal of International Women's Studies Nepali Women in Politics: Success and Challenges. 21(2), 76-93.

Samjhauta Nepal. (2018). Nepal's Locally Elected Women Representatives Exploratory Study of Needs and Capacity.

Schwarz, N., Groves, R. M., \& Schuman, H. (1999). Survey methods. Survey Methodology Program, Institute for Social Research, University of Michigan.

\section{APPENDIX - 1}

\begin{tabular}{lccl}
\hline \multicolumn{1}{c}{ Name } & Number & Date & \multicolumn{1}{c}{ Location } \\
\hline $\begin{array}{l}\text { Sagun } \\
\text { Gurung }\end{array}$ & Respondent 1 & 15 June, 2021 & Annapurna Rural Municipality, Kaski \\
$\begin{array}{l}\text { Krishna } \\
\text { Kumari }\end{array}$ & Respondent 2 & 16 June, 2021 & $\begin{array}{l}\text { Machhapuchhre Rural Municipality, } \\
\text { Kaski }\end{array}$ \\
$\begin{array}{l}\text { Dawadi } \\
\text { Baudel }\end{array}$ & & & \\
Lalsova & Respondent 4 & 18 June, 2021 & Annapurna Rural Municipality, Kaski \\
Gurung & & & \\
Manju & Respondent 5 & 25 June, 2021 & Pokhara Rural Municipality, Kaski \\
Gurung & & & \\
Harimaya & Respondent 6 & 25 June, 2021 & Pokhara Rural Municipality, Kaski \\
BK & & & \\
$\begin{array}{l}\text { Gita } \\
\text { Sapkota }\end{array}$ & Respondent 7 & 25 June, 2021 & Madi Rural Municipality, Kaski \\
\hline
\end{tabular}

